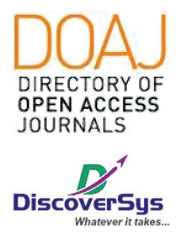

Published by DiscoverSys

\section{Analisis nilai diagnostik C-reactive protein pada pasien pediatrik dengan apendisitis di RSUP Dr. Wahidin Sudirohusodo, Makassar, Indonesia}

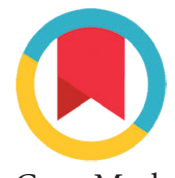

CrossMark

\author{
Hermawan, ${ }^{1 *}$ Darwati Muhadi, ${ }^{2}$ lbrahim Abdul Samad ${ }^{3}$
}

\section{ABSTRACT}

Background : Acute appendicitis associated with acute phase reaction is the most prevalent disease which requires emergency surgery. Its delayed diagnosis and unnecessarily performed appendectomies lead to numerous complications. In our study, we aimed to detect the role of C-reactive protein (CRP) in the exclusion of acute and complicated appendicitis and diagnostic accuracy in pediatric age group.

Methods : A retrospective analytic observational study with crosssectional design was performed on 69 children with definitive appendicitis. Appendectomized patient groups were constructed based on the results of histopathological evaluation. The area under a receiver operating characteristic (ROC) curve (AUC) was performed to examine diagnostic accuracy.

Results : Based on cut-off values of $\geq 22,6 \mathrm{mg} / \mathrm{dL}$ for CRP level, diagnostic parameters were as follow : sensitivity $97,4 \%$, specificity $80,0 \%$, PPV $97,4 \%$, NPV 80,0\%, and diagnostic accuracy $89,9 \%$. AUC values were 0,98 (95\% Cl 0,96-9,99) for CRP.

Conclusion : For complicated appendicitis, CRP has the highest degress of diagnostic accuracy. The diagnosis appendicitis should be made primarily based on clinical examination, and obviously more specific and systemic inflammatory markers are needed. Cut-off values of CRP $\geq$ $22,6 \mathrm{mg} / \mathrm{dL}$ provides discrimination values for complicated appendicitis.
1Program Pendidikan Dokter Spesialis IImu Patologi Klinik FK UNHAS / RSUP Dr. Wahidin Sudirohusodo, Makassar, Indonesia ${ }^{2}$ Departemen IImu Patologi Klinik FK UNHAS / RSUP Dr. Wahidin Sudirohusodo, Makassar, Indonesia ${ }^{3}$ Departemen IImu Patologi Klinik FK UNHAS / RS. Ibnu Sina, Makassar, Indonesia

*Korespondensi: Hermawan; Program Pendidikan Dokter Spesialis IImu Patologi Klinik FK UNHAS / RSUP Dr. Wahidin Sudirohusodo, Makassar, Indonesia, celexib@gmail.com

Diterima: 25-02-2019

Disetujui: 17-04-2019

Diterbitkan: 01-08-2019

Keyword : appendicitis, CRP, pediatric.

Cite This Article: Hermawan, Muhadi, D., Samad, I.A. 2019. Analisis nilai diagnostik C-reactive protein pada pasien pediatrik dengan apendisitis di RSUP Dr. Wahidin Sudirohusodo, Makassar, Indonesia. Intisari Sains Medis 10(2): 408-412. D0I: 10.15562/ism.v10i2.417

\title{
ABSTRAK
}

Latar belakang : Apendisitis akut yang berhubungan dengan reaksi fase akut merupakan penyakit yang sering kali memerlukan tindakan pembedahan. Penundaan diagnosis dan melakukan tindakan apendektomi yang tidak semestinya menyebabkan sejumlah komplikasi. Pada penelitian ini, kami bertujuan untuk menemukan peranan C-reactive protein (CRP) dalam mengekslusi apendisitis akut dan komplikata dan akurasi diagnosisnya terhadap kelompok usia pediatrik.

Metode : Penelitian observasional analitik retrospektif dengan desain potong lintang ini dilakukan pada 69 anak dengan apendisitis definitif. Pasien paska tindakan apendektomi dibagi berdasarkan hasil pemeriksaan histopatologi. Area under a receiver operating characteristic (ROC) curve (AUC) dilakukan untuk menilai akurasi diagnostik.

Hasil : Berdasarkan nilai cut-off sebesar $\geq 22,6 \mathrm{mg} / \mathrm{dL}$ untuk kadar CRP, parameter diagnostik yang ditunjukkan : sensitivitas $97,4 \%$, spesifisitas 80,0\%, PPV 97,4\%, NPV 80,0\%, dan akurasi diagnostik $89,9 \%$. Nilai AUC adalah 0,98 (95\% Cl 0,96-9,99) terhadap CRP.

Kesimpulan : Untuk apendisitis komplikata, CRP memiliku nilai akurasi diagnostik yang baik. diagnosis apendisitis sebaiknya ditegakkan berdasarkan pemeriksaan klinis, dan sejumlah parameter inflamasi sistemik yang spesifik. Nilai cut-off CRP sebesar $\geq$ $22,6 \mathrm{mg} / \mathrm{dL}$ memberikan nilai diskriminasi diagnosis yang baik terhadap apendisitis komplikata.

Kata kunci : apendisitis, CRP, pediatrik

Cite Pasal Ini: Hermawan, Muhadi, D., Samad, I.A. 2019. Analisis nilai diagnostik C-reactive protein pada pasien pediatrik dengan apendisitis di RSUP Dr. Wahidin Sudirohusodo, Makassar, Indonesia. Intisari Sains Medis 10(2): 408-412. D0I: 10.15562/ism.v10i2.417

\section{PENDAHULUAN}

Apendisitis merupakan suatu radang appendiks vermiformis yang merupakan penyebab paling sering dari gangguan akut pada abdomen. Karakteristik gejala dari apendisitis diantaranya muntah, demam, dan nyeri abdomen pada regio kuadran kanan bawah. Apendisitis pediatrik memiliki gambaran klinis yang tidak khas, dan gejala yang ditimbulkan mirip dengan intususepsi, gastroenteritis, pneumonia, dan sejumlah besar penyakit lainnya. Insiden apendisitis pediatrik adalah sebesar $1-8 \%$ dari 
populasi anak-anak dan insidennya paling banyak dialami anak pada kelompok usia 10-17 tahun. ${ }^{1}$

Apendisitis sering ditemui pada usia kanakkanak yang memerlukan pembedahan abdomen yang segera. Diagnosis umumnya berdasarkan anamnesis, pemeriksaan klinis, dan evaluasi klinis. Penegakan diagnosis sangat sulit dilakukan terutama pada kelompok usia anak-anak. Penggunaan computed tomography dan ultrasonografi hanya dapat menurunkan sedikit insiden apendektomi negatif. Karena lemak tubuh yang secara relatif kurang menonjol pada anak-anak, sangat sulit untuk membedakan usus dari apendiks yang mengalami inflamasi. Oleh karena itu, pada orang dewasa, CT memiliki sensitivitas dan spesifisitas yang lebih tinggi (97 dan 94\%, masing-masing), sementara pada anak-anak CT memiliki akurasi diagnostik yang secara relatif lebih rendah (50\%). Meskipun demikian, CT lebih memakan biaya karena pemeriksaan ini memerlukan sedasi sebelum pasien mendapatkan tindakan. CT akan menyebarkan radiasi pada pasien, dan reaksi sensitivitas dapat lebih sering ditemukan dengan penggunaan agen kontras. ${ }^{2}$

Pada apendisitis akut, penyumbatan lumen apendiks menyebabkan gangguan aliran darah dan kerusakan mukosa. Setelah itu, proliferasi bakteri dan infiltrasi leukosit akan timbul pada area yang mengalami gangguan tersebut. Migrasi leukosit menuju jaringan target menyebabkan pelepasan C-reactive protein (CRP). ${ }^{3}$

Inflamasi akibat infeksi bakteri bertanggung jawab terhadap sebagian besar patogenesis penyakit ini, dewasa maupun anak-anak. Kondisi inilah yang memberikan pandangan untuk menggunakan parameter-parameter inflamasi. C-reactive protein (CRP) yang dikenal sebagai suatu mediator inflamasi non-spesifik yang ditemukan pada tahun 1930 oleh Tillett dan Francis, merupakan suatu protein fase akut disintesis dari hepatosit, memiliki struktur pentamer siklik $115 \mathrm{kDa}$ yang sensitif terhadap adanya infeksi bakteri, peradangan, dan kerusakan jaringan. ${ }^{1,4}$ Kadar normalnya berkisar $<5 \mathrm{mg} / \mathrm{L}$ dan meningkat dalam waktu $8-12$ jam setelah terjadinya infeksi atau trauma. ${ }^{5,6,7}$ Namun, menggunakan parameter ini terhadap penegakan diagnosis apendisitis menunjukkan hasil yang berbeda-beda dan bersifat kontroversial. ${ }^{6,89}$ Berdasarkan penelitian yang dilakukan oleh Kwan KY dan Nager AL telah menemukan bahwa nilai CRP $>30 \mathrm{mg} / \mathrm{L}$ secara signifikan mampu membedakan apendisitis pediatrik dari diagnosis lainnya dengan nilai sensitivitas sebesar 70\% (95\% CI, 60 - 79) dan spesifisitas 65\% (95\% CI, $53-75 \%){ }^{10}$

Penundaan diagnosis menyebabkan komplikasi-komplikasi serius seperti misalnya peritonitis difus, abses hepar, abses abdomen atau abses retroperitoneal, dan fistula apendikovesikal. Insiden perforasi apendiks akibat penundaan diagnosis lebih banyak ditemukan pada anak-anak dibandingkan orang dewasa. ${ }^{1,6}$ Kondisi ini meningkatkan kepentingan untuk mencari parameter-parameter inflamasi sederhana yang lain untuk membantu mempersingkat penegakan diagnosis apendisitis pada anak. Dengan melihat potensi akurasi CRP dalam membantu menegakkan diagnosis apendisitis pediatrik, maka dilakukan penilaian terhadap tingkat akurasi diagnosik CRP sebagai suatu prediktor apendisitis pediatrik.

\section{METODE PENELITIAN}

\section{Rancangan Penelitian}

Rancangan penelitian ini berupa cross sectional yang bersifat analitik observasional retrospektif dengan mengambil data sekunder dari rekam medis pasien yang dirawat di RSUP Dr. Wahidin Sudirohusodo dari bulan Januari-Desember 2017. Penelitian dilakukan di Instalasi Laboratorium Patologi Klinik dan Instalasi Rekam Medis RSUP Dr. Wahidin Sudirohusodo yang dimulai dari bulan Juli-Agustus 2018. Sampel penelitian adalah data klinis pasien apendisitis pediatrik (usia $<18$ tahun). ${ }^{11}$ Apendisitis pediatrik didefinisikan sebagai suatu peradangan pada apendiks yang ditegakkan melalui diagnosis kerja dari klinisi bedah anak kemudian secara definitif ditegakkan dengan tindakan laparoskopik yang disertai dengan pemeriksaan histopatologis. Data yang akan dicatat diantaranya, data karakteristik pasien (usia dan jenis kelamin) dan kadar CRP awal. Kadar CRP diperiksa dengan menggunakan alat $A B X$ Horriba Pentra $400^{\circ}$ dengan metode imunoturbidimetri dan ditunjukkan dalam satuan milligram per desiliter (mg/dL). Kadar CRP dianggap normal jika nilainya $<0,5 \mathrm{mg} / \mathrm{dL}$.

\section{Analisis Data}

Untuk analisis statistik, Statistical Package for Social Sciences (SPSS) (SPSS Inc, perangkat lunak versi 15, Chicago, Illionois, Amerika Serikat) dalam perangkat lunak Windows akan digunakan. Untuk statistik deskriptif, variabel kategori akan ditunjukkan dalam bentuk angka, dan persentase sedangkan variabel numerik akan ditunjukkan dalam bentuk rata-rata \pm standar deviasi (SD). Independent- $t$ test akan digunakan untuk membandingkan antara dua kelompok independen. Perbandingan antara variabel-variabel kategorik antara kelompok-kelompok akan menggunakan uji chi kuadrat. Untuk memaparkan peranan diagnostik dari kadar CRP, maka akan digunakan area under ROC curve (AUC). Nilai cut-off akan dipilih untuk menilai sensitivitas, spesifisitas, PPV, NPV dan akurasi 
diagnostik. Seluruh hasil dilaporkan dalam 95\% confidence intervals ( $95 \% \mathrm{CI})$. Nilai $p<0,05$ akan dianggap signifikan secara statistik.

\section{HASIL}

Penelitian dilakukan terhadap 69 subjek terdiri dari 45 anak laki-laki dan 24 anak perempuan yang berusia sekitar $8-18$ tahun (rata-rata 13,2 $\pm 2,7$ tahun) yang dibagi menjadi dua buah kelompok : apensiditis komplikata (23,1\%), yang secara definisi, apendisitis komplikata diantaranya perforasi apendiks, pembentukan empiema atau abses dan

\section{ROC Curve}

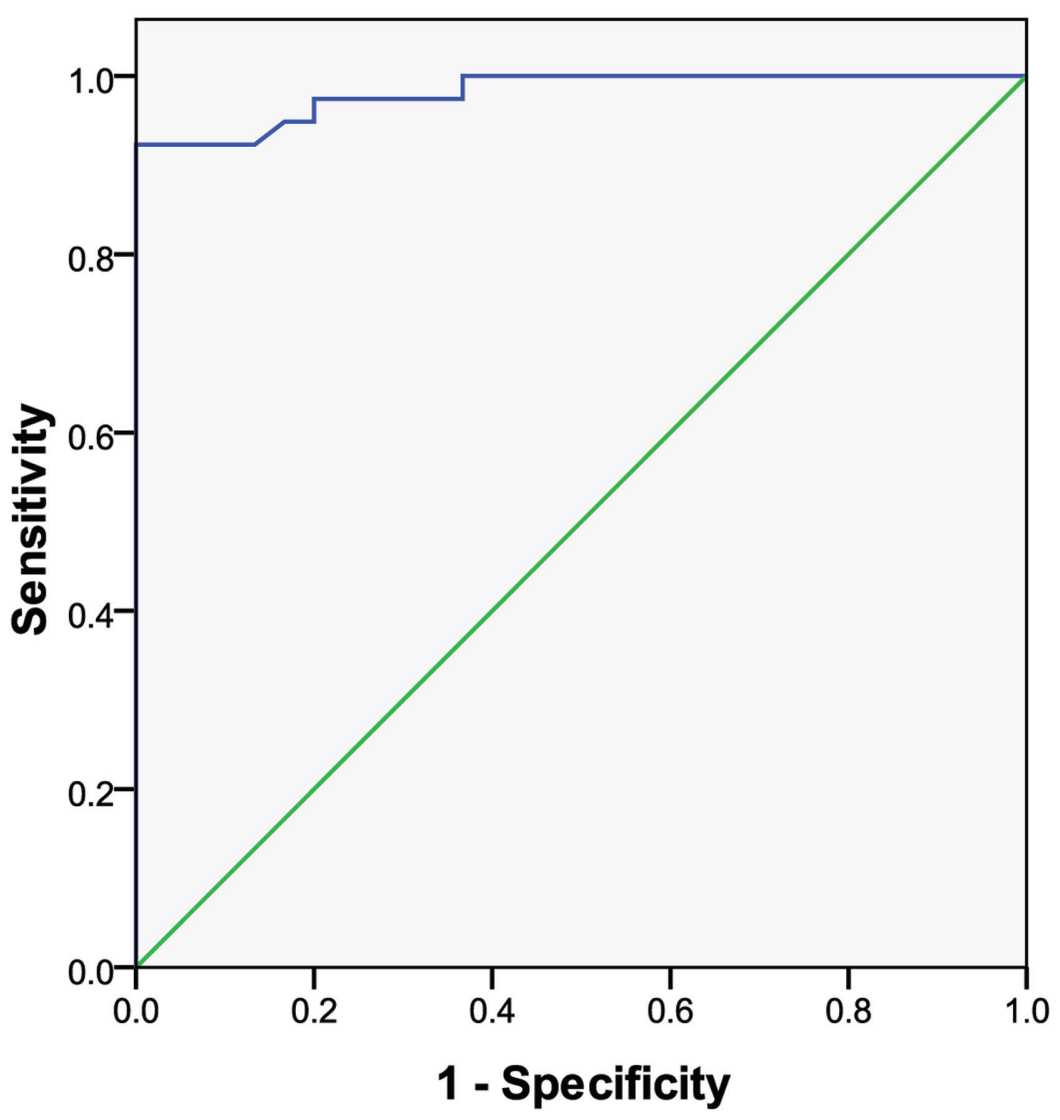

Gambar 1 Kurva receiver operating characteristic (ROC) yang disertai dengan area under curve (AUC) C-reactive protein (CRP) dalam memprediksi apendisitis komplikata. peritonitis fekal yang dibuktikan paska tindakan appendektomi dan apendisitis akut $(76,9 \%) \cdot{ }^{10}$ Ratarata usia kelompok pasien apendisitis komplikata secara relatif lebih tinggi dibandingkan dengan kelompok pasien apendisitis akut $(P=0,34)$. Tidak ada perbedaan yang signifikan secara statistik pada rasio jenis kelamin laki-laki/perempuan $(P=0,77)$. Pada kelompok-kelompok pasien apendisitis tersebut ditemukan adanya perbedaan yang signifikan secara statistik pada kadar CRP, yakni kelompok pasien apendisitis komplikata memiliki nilai yang lebih tinggi dibandingkan dengan kelompok pasien apendisitis akut (Tabel 1).

Pada pasien dengan apendisitis komplikata, parameter diagnostik CRP dengan nilai cut-off sebesar 22,6 mg/dL dianggap memiliki tingkat sensitivitas dan spesifisitas tertinggi; sensitivitas, 97,4\%; spesifisitas, 80,0\%; PPV, 97,4\%; NPV, 80,0\%; akurasi diagnostik, $89,9 \%$. Nilai AUC adalah 0,98 $[P<0,001 ; 95 \%$ confidence interval (CI) $0,96-0,99]$ terhadap CRP (Gambar 1).

\section{PEMBAHASAN}

Sintesis CRP dari hepatosit meningkat dalam 8 12 jam setelah cedera jaringan akut atau onset inflamasi, dan meningkat berlipat ganda setiap 8 jam sehingga puncaknya berkisar 36 - 50 jam. Karena waktu paruhnya hanya $4-7$ jam, konsentrasinya menurun secara cepat. Oleh karena itu, pada pasien yang memiliki menifestasi klinis yang kurang dari 12 jam, CRP akan menunjukkan sensitivitas yang lebih rendah. ${ }^{3}$

Telah dilaporkan bahwa CRP yang digunakan secara tunggal ataupun dikombinasi dengan hitung leukosit efektif untuk membedakan apendisitis akut dan komplikata. Pada penelitian kami, nilai CRP meningkat secara signifikan pada apendisitis komplikata. Peningkatan kadar CRP mengindikasikan suatu tahapan penyakit apendisitis yang lebih lanjut. Oleh karena itu, CRP memiliki akurasi diagnostik terhadap apendisitis yang paling baik, sehingga kadar CRP sebaiknya diperiksa secara rutin pada pasien dengan dignosis awal apendisitis. Pada penelitian kami, ditemukan akurasi uji diagnostik CRP yang sangat baik (AUC : 0,98). Hasil tersebut sama dengan hasil penelitian yang

Tabel 1 Karakteristik dasar pasien pediatrik dengan apendisitis

\begin{tabular}{|c|c|c|c|c|c|c|c|c|}
\hline & & \multirow{2}{*}{$\begin{array}{c}\text { Usia (tahun) } \\
\text { Mean } \pm \text { SD }\end{array}$} & \multirow[b]{2}{*}{$\mathbf{P}$} & \multicolumn{2}{|c|}{ Jenis kelamin n(\%) } & \multirow[b]{2}{*}{$\mathbf{P}$} & \multirow{2}{*}{$\begin{array}{c}\text { CRP }(\mathrm{mg} / \mathrm{dL}) \\
\text { Mean } \pm \mathrm{SD}\end{array}$} & \multirow[b]{2}{*}{$\mathbf{P}$} \\
\hline & & & & Laki-laki & Perempuan & & & \\
\hline \multirow[t]{2}{*}{ Apendisitis } & Akut & $13,2 \pm 2,8$ & \multirow{2}{*}{$0,34^{\mathrm{a}}$} & $26(57,8)$ & $13(54,2)$ & \multirow{2}{*}{$0,77^{\mathrm{b}}$} & $11,7 \pm 5,8$ & \multirow{2}{*}{$<0,001^{\mathrm{a}}$} \\
\hline & Komplikata & $13,8 \pm 2,7$ & & $19(42,2)$ & $11(43,5)$ & & $26,6 \pm 5,1$ & \\
\hline
\end{tabular}

\footnotetext{
a : Independent-t test
}

${ }^{\mathrm{b}}$ : Chi-square test 
dilakukan oleh Parashar D et al, yang menyimpulkan bahwa CRP memiliki nilai diskriminasi terhadap apendisitis komplikata yang sangat baik dengan nilai AUC sebesar 0,93 (95\% CI: 0,90 - 0,96). ${ }^{12}$

Analisa kurva ROC memungkinkan untuk mengevaluasi validitas parameter-parameter diagnostik dan akurasi diagnosis. Berdasarkan nilai cut-off yang kami perkirakan, diperoleh nilai dengan tingkat sensitivitas dan spesifisitas yang terbaik. Berdasarkan penelitian yang dilakukan oleh Klempa I, untuk apendisitis komplikata, nilai cut-off CRP $\geq 1,17 \mathrm{mg} / \mathrm{dL}$, akan menunjukkan sensitivitas sebesar $86,1 \%$; spesifisitas $81,9 \%$; PPV 58,6\%; NPV 95,2\%; akurasi diagnosis 77,7\%. Sementara pada penelitian yang melibatkan subjek yang mendapatkan pembedahan, memberikan kesan bahwa CRP mungkin lebih sensitif (83\% $>90 \%$ ) dalam mendeteksi perforasi apendiks dan pembentukan abses, kondisi yang lebih sering ditemukan pada anak-anak. ${ }^{13}$

Pada penelitian kami, tingkat sensitivitas dan spesifisitas ditemukan sebesar $97,4 \%$ dan $80,0 \%$, masing-masing, dengan nilai cut-off sebesar 22,6 $\mathrm{mg} / \mathrm{dL}$. Variasi sensitivitas dan spesifisitas ini mungkin berasal dari adanya perbedaan interval antara onset nyeri perut dan pemeriksaan penanda-penanda inflamasi.

Penelitian yang dilakukan Andersson $\mathrm{M}$ et al dan Yu CW et al pada pasien pediatrik, penanda diagnostik seperti IL-8, IL-10, granulosit, colony-stimulating factor, interferon $\gamma$, intercellular adhesion molecule-1, dan matrix metalloproteinase-9 belum menunjukkan manfaat yang sangat baik dalam membuat diagnosis banding dari nyeri abdomen. Hingga saat ini, dalam penegakan diagnosis apendisitis, banyak penanda-penanda yang baru seperti prokalsitonin, yang memiliki akurasi diagnostik yang lebih baik dibandingkan CRP, belum diteliti secara rinci. ${ }^{14,15}$

\section{SIMPULAN}

Penegakan diagnosis apendisitis merupakan suatu tantangan pada kelompok usia pediatrik. Karena insiden perforasi cukup tinggi pada anak-anak, diagnosis yang tepat akan memungkinkan intervensi pembedahan sebelum timbulnya perforasi, dan juga memungkinkan untuk mempercepat tindakan pembedahan jika ditemukan apendisitis komplikata. Untuk apendisitis komplikata, CRP memiliki tingkat akurasi diagnostik yang sangat baik.

Dengan nilai cut-off CRP sebesar 22,6 mg/dL, pemeriksaan ini menunjukkan nilai sensitivitas sebesar $97,4 \%$ dan spesifisitas sebesar $80 \%$ untuk menegakkan diagnosis apendisitis komplikata. Seperti halnya nilai diagnostik pemeriksaan fisik dan uji-uji laboratorium yang tersedia saat ini, dalam melakukan evaluasi akurasi diagnostik dari kadar CRP, waktu interval antara onset nyeri abdomen dan analisa perbandingan dengan parameter inflamasi lain sebaiknya turut dipertimbangkan.

\section{ETIKA PENELITIAN}

Penelitian ini telah mendapatkan izin dari Komisi Etik Penelitian Kesehatan Fakultas Kedokteran Universitas Hasanuddin - RSUP dr. Wahidin Sudirohusodo Makassar.

\section{KONFLIK KEPENTINGAN}

Tidak terdapat konflik kepentingan dalam penulisan laporan penelitian.

\section{PENDANAAN}

Penelitian ini didanai oleh peneliti tanpa adanya bantuan pendanaan dari pihak sponsor, grant, atau berbagai sumber pendanaan.

\section{KONTRIBUSI PENULIS}

Seluruh penulis memiliki kontribusi yang sama dalam mempersiapkan laporan penelitian baik dari penyusunan draft tulisan, ekstraksi data penelitian, analisis data penelitian, hingga pembahasan.

\section{DAFTAR PUSTAKA}

1. Suhaymi E, Fikri E, dan Adeputra Nasution IP. Perbandingan Akurasi Diagnostik Kadar Procalcitonin dan C-Reactive Protein pada pasien Appendisitis Anak di RSUP H. Adam Malik Medan dan RSUD Dr. Pirngadi Medan. CDK. 2016;43:727-728.

2. Sayed AO, Zeidan NS, Fahmy DM, dan Ibrahim HA. Diagnostic reliability of pediatric appendicitis score, ultrasound and low-dose domputed tomography scan in children with suspected acute appendicitis. Therapeutics and Clinical Risk Management. 2017;13:847-854.

3. Yokoyama S, Takifuji K, Hotta T, Matsuda K, Nasu T, Nakamori M, et. al. C-Reactive protein is an independent surgical indication marker for appendicitis: a retrospective study. World Journal of Emergency Surgery. 2009;4:36.

4. Iskandar HR, Pudjiadi A, Mulyo D, Pratiwi A, dan Suryatin Y. Sensitifitas dan Spesifitas Pemeriksaan Procalcitonin, C-Reactive Protein (CRP), dan Hitung Jumlah Leukosit untuk Memprediksi Infeksi Bakterial pada Sindrom Syok Dengue di Pediatrik Intensive Care Unit. Sari Pediatri. 2010;4:234.

5. Najeeb M, Jose J, Thomas VP, dan Raja KCN. Evaluation of Diagnostic Accuracy of C-Reactive Protein and Leucocyte Count in Operated Cases of Suspected Acute Appendicitis. IOSR J. 2015;14:20-22.

6. Ali WA, Bonila JA, Yammahi AA, Badri F, dan Tayeb YH. Can a Negative C-Reactive Protein Rule Out Appendicitis?. Glob J Med Researc. 2013;13:5-6.

7. Dirk HS, Hulsere WE, van Acker BS, van Bijnen AA, de Jaegere TM, Sastrowijoto $\mathrm{SH}$, et. al. Evaluation of the Diagnostic Accuracy of Plasma Markers for Early Diagnosis in Patients Suspected for Acute Appendicitis. Academic Emergency Medicine. 2013;20:703-704. 
8. John S, Joseph J, dan Shetty S. Avoiding negative appendectomies in rural surgical practice: is Creactive protein estimation useful as a diagnostic tool?. The National Medical Journal of India. 2011; 24(3):144-147.

9. Jangjoo A, Varasteh A, Amouzeshi A, et al. Is Creactive protein helpful for early diagnosis of acute appendicitis? Acta Chirurgica Belgica. 2011; 111(4):219-222.

10. Kwan KY, dan Nager AL. Diagnosis pediatric appendicitis : usefulness of laboratory markers. American Journal of Emergency Medicine. 2010;28:1009-11.

11. Kemenkes RI. Kondisi Pencapaian Program Kesehatan Anak Indonesia. Infodatin Kemenkes RI. 2014:2.

12. Parashar D, Panagiotopoulou IC, Lin R, Antonowicz S, Wells AD, Bajwa FM, et. al. The diagnostic value of white cell count, C-reactive protein and bilirubin in acute appendicitis and its complications. Surg Engl. 2013;95(3): $215-219$.

13. Klempa I. Current therapy of complicated appendicitis. Chirrurg. 2002;73(8):799-800.
14. Andersson M, Ruber M, Ekerfelt C, Hllgren HB, Olaison G, Andersson RE. Can New Inflammatory Markers Imrpove the Diagnosis of Acute Appendicitis?. World J Surg. 2014;11:2777-83

15. Yu CW, Juan LI, Wu MH, Shen CJ, Wu Jy, dan Lee CC. Systemic review and meta-analysis of the diagnostic accuracy of procalcitonin, C-reactive protein and white blood cell count for suspected acute appendicitis. British Journal of Surgery. 2013;11(3):322-29.

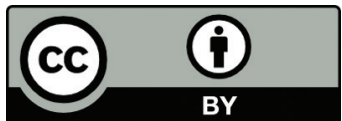

This work is licensed under a Creative Commons Attribution 